\title{
New species of Muricidae (Gastropoda) and additional or noteworthy records from the western Pacific
}

\author{
Roland HOUART \\ Research Associate \\ Institut royal des Sciences naturelles de Belgique \\ rue Vautier, 29, B-1000 Bruxelles (Belgium) \\ roland.houart@skynet.be
}

Virginie HÉROS

Muséum national d'Histoire naturelle,

Département systématique \& évolution

case postale 51, 57 rue Cuvier, 75231 Paris cedex 5 (France)

malaco@mnhn.fr

KEY WORDS

Gastropoda,

Muricidae,

New Caledonia,

Coral Sea,

Solomon Islands,

Vanuatu,

Taiwan,

new species,

new data,

new combinations.

MOTS CLÉS

Gastropoda,

Muricidae,

Nouvelle-Calédonie, mer de Corail,

îles Salomon,

Vanuatu,

Taiwan,

espèces nouvelles,

données nouvelles, combinaisons nouvelles.
Houart R. \& Héros V. 2012. - New species of Muricidae (Gastropoda) and additional or noteworthy records from the western Pacific. Zoosystema 34 (1): 21-37. DOI: http://dx.doi. org/10.5252/z2012n1a2

\section{ABSTRACT}

Fourteen species of Muricidae referable to the (sub)genera Promurex Ponder \& Vokes, 1988, Pygmaepterys Vokes, 1978, Murexsul Iredale, 1915, Pazinotus Vokes, 1970, Prototyphis Ponder, 1972, Ponderia Houart, 1986, Gemixystus Iredale, 1929, Leptotrophon Houart, 1995 and Scabrotrophon McLean, 1996 are reported from New Caledonia, the Solomon Islands and Taiwan, to depths down to $1750 \mathrm{~m}$. Five new species are described: Favartia (Pygmaepterys) lifouensis n. sp. from New Caledonia with range extension to the Solomon Islands, Pazinotus chionodes n. sp. and Gemixystus calcareus n. sp. from New Caledonia, Leptotrophon wareni n. sp. from the Solomon Islands and Favartia (Pygmaepterys) circinata n. sp. from Taiwan.

\section{RÉSUMÉ}

Nouvelles espèces de Muricidae (Gastropoda) et signalisations additionnelles ou intéressantes pour le Pacifique occidental.

Quatorze espèces de Muricidae appartenant aux (sous-)genres Promurex Ponder \& Vokes, 1988, Pygmaepterys Vokes, 1978, Murexsul Iredale, 1915, Pazinotus Vokes, 1970, Prototyphis Ponder, 1972, Ponderia Houart, 1986, Gemixystus Iredale, 1929, Leptotrophon Houart, 1995 et Scabrotrophon McLean, 1996 sont mentionnées de Nouvelle-Calédonie, des îles Salomon et de Taiwan, jusqu’à une profondeur de $1750 \mathrm{~m}$. Cinq espèces nouvelles sont décrites: Favartia (Pygmaepterys) lifouensis n. sp. de Nouvelle-Calédonie avec une distribution s'étendant jusqu'aux îles Salomon, Pazinotus chionodes n. sp. et Gemixystus calcareus n. sp. de Nouvelle-Calédonie, Leptotrophon wareni n. sp. des îles Salomon et Favartia (Pygmaepterys) circinata n. sp. de Taiwan. 


\section{INTRODUCTION}

More than 50 expeditions conducted by MNHN and IRD (formerly ORSTOM) have been spread all over the tropical Indo-West Pacific since 1976, leading to the discovery of hundreds new species of marine organisms in which Mollusca occupy a significant place, and was the subject of many reports in the voluminous series of Deep-Sea Benthos (formerly "Résultats des campagnes MUSORSTOM") and in numerous other publications (Bouchet et al. 2008). The Muricidae collected during these cruises are studied since early in the 1980s (Houart 1983). Since then a high number of new species have been described from the reported material, mostly from the tropical Pacific, while numerous range extensions have been signalized. The present paper deals with 14 species of which five are new. Five have seen their range extended to New Caledonia (Murexsul merlei Houart \& Héros, 2008 and Prototyphis gracilis Houart \& Héros, 2008) and to Solomon Islands (Pazinotus brevisplendoris Houart, 1985, Pazinotus falcatiformis (Thiele, 1925) and Scabrotrophon inspiratum Houart, 2003). Two species are new combinations: Leptotrophon minirotundus (Houart, 1986) and Leptotrophon segmentatus (Verco, 1909). The radula is illustrated for the first time for Scabrotrophon inspiratum. The classification is maintained in a conservative way (Houart 2010), waiting for future study of the molecular characters when more and adequate material will be available (Barco et al. 2010).

\section{MATERIAL AND METHODS}

The present report deals with species collected during nine expeditions: BATHUS 1 and 3 (1993), ATELIER LIFOU 2000 (all New Caledonia), EBISCO (2005) (Coral Sea), MUSORSTOM 8 (1994) (Vanuatu), SALOMON 1 (2001), SALOMON 2 (2004), and SALOMONBOA 3 (2007) (all Solomon Islands), TAIWAN 2002 (Taiwan).

All the material belongs to MNHN otherwise mentioned.

\section{ABBREVIATIONS}

Repositories

coll. RH collection Roland Houart;

IRD Institut de Recherche pour le Développement (formerly ORSTOM: Office de la Recherche scientifique et technique Outre-Mer);

MNHN Muséum national d'Histoire naturelle, Paris; NMMBM National Museum of Marine Biology and Aquarium, Checheng, Pingtung, Taiwan;

ZMB Museum für Naturkunde der Humboldt Universität zu Berlin, zoologisches Museum, Berlin.

\section{Field work \\ $\mathrm{CP} \quad$ chalut à perche (Beam trawl); \\ DW drague Warén (Warén dredge).}

\section{Specimens \\ dd empty shell; \\ lv live-taken specimen.}

\section{Terminology used to describe the spiral cords and} apertural denticles (after Merle 1999 and 2001)

Terminology in parentheses: erratic feature (Fig. 3C). abis abapical infrasutural secondary cord (on subsutural ramp);

ABP abapertural primary cord on the siphonal canal;

adis adapical infrasutural secondary cord (on subsutural ramp);

ADP adapertural primary cord on the siphonal canal;

ads adapertural secondary cord on the siphonal canal;

EABP extreme abapertural primary cord on the siphonal canal (e.g., EABP2 = between EABP1 and $\mathrm{EABP} 3$ );

IP infrasutural primary cord on subsutural ramp; MP median primary cord on the siphonal canal; P primary cord;

P1 shoulder cord;

P2-P6 primary cords of the convex part of the teleoconch whorl;

s secondary cord;

s1-s6 secondary cords of the convex part of the teleoconch whorl (e.g., s1 = secondary cord between P1 and P2; s2 = secondary cord between $\mathrm{P} 2$ and $\mathrm{P} 3$, etc.);

SP subsutural cord.

Aperture

D1-D6 abapical denticles;

ID infrasutural denticle. 


\section{SYSTEMATICS}

Family MURICIDAE Rafinesque, 1815

Subfamily MURICINAE Rafinesque, 1815

Genus Murex Linnaeus, 1758

Subgenus Promurex Ponder \& Vokes, 1988

TYPE SPECIES (by original designation). - Murex antelmei Viader, 1938, Recent, Mauritius.

Murex (Promurex) protocrassus Houart, 1990

(Fig. 4A, B)

Murex (Murex) protocrassus Houart, 1990: 330, figs 1-3, 26.

TYPe MATERIAL. - Holotype MNHN 0939.

New Material eXamined. - Coral Sea. EBISCO: stn CP2492, Capel Bank, 244'S, 15941'E, 285 m, 1 dd (MNHN).

Type locality. - Coral Sea, Chesterfields, $19^{\circ} 40^{\prime}$ S, 158 32'E, 305-310 m [MUSORSTOM 5: stn DC345].

DistRibuTION. - Coral Sea, bathymetric range unknown for living specimens. This is the 4th known specimen; all were collected as shells only. This record extends the geographical distribution southwards. The type material range is $19^{\circ} 36^{\prime}-19^{\circ} 42^{\prime} \mathrm{S}, 158^{\circ} 30^{\prime}-158^{\circ} 32^{\prime} \mathrm{E}$.

\section{REMARKS}

The shell of Murex protocrassus is similar to those of the various subspecies of $M$. brevispina (M. brevispina brevispina Lamarck, 1822, M. brevispina macgillivrayi Dohrn, 1862, M. brevispina senilis Jousseaume, 1874, and M. brevispina ornamentalis Ponder \& Vokes, 1988) but differs from them in its more numerous axial ridges on the early teleoconch whorls and in its more spinose siphonal canal. Other differences are its large and broad protoconch, which indicates intracapsular larval development, and the absence of a labral tooth.

Due to the lack of the labral tooth it cannot be classified in Murex s.s. It is therefore included in Promurex as in Merle et al. (2011).

The French fossil Murex spinicosta Bronn, 1831 (Fig. 4C), another species without a labral tooth, was classified in Promurex by Ponder \& Vokes (1988: 15), and was illustrated by Landau et al. (2007).
Subfamily MURICOPSINAE

Radwin \& D'Attilio, 1971

Genus Favartia Jousseaume, 1880

Subgenus Pygmaepterys Vokes, 1978

TYPE SPECIES (by original designation). - Murex alfredensis Bartsch, 1915, Recent, South Africa.

Favartia (Pygmaepterys) lifouensis n. sp.

(Fig. 1A-D, K, L)

Type Material. - Holotype (dd) MNHN 24174; 5 paratypes (dd) MNHN 24175-24177; 1 paratype (dd) coll. RH.

Material examined. - New Caledonia. ATELIER LIFOU 2000: stn 1423, Loyalty Islands, Lifou, Baie du Santal, off Peng, $20^{\circ} 54^{\prime} \mathrm{S}, 167^{\circ} 07^{\prime} \mathrm{E}, 12 \mathrm{~m}, 1 \mathrm{dd}$, paratype MNHN 24175. - Stn 1442, Lifou, Baie du Santal, Aimé Martin Cape, $20^{\circ} 46$ 'S, $167^{\circ} 02^{\prime} \mathrm{E}, 47 \mathrm{~m}, 1 \mathrm{dd}$, paratype coll. RH. - Stn 1445, Lifou, east of Baie du Santal, $20^{\circ} 51^{\prime} \mathrm{S}, 167^{\circ} 10^{\prime} \mathrm{E}, 10-12 \mathrm{~m}, 1 \mathrm{dd}$, paratype MNHN 24176. - Stn 1461, Lifou, Baie du Santal, Shelter Reef, $20^{\circ} 54^{\prime} \mathrm{S}, 167^{\circ} 02^{\prime} \mathrm{E}, 100-120 \mathrm{~m}, 1 \mathrm{dd}$, holotype MNHN 24174. - BATHUS 1: stn DW692, east coast, 203' S, 1645ํ'E, 140-150 m, 3 dd, paratypes MNHN 24177. Solomon Islands. SALOMONBOA 3: stn DW2840, W San Cristobal, $10^{\circ} 25^{\prime} \mathrm{S}, 161^{\circ} 22^{\prime} \mathrm{E}, 121-180 \mathrm{~m}, 1 \mathrm{dd}$, MNHN. - Stn DW2841, $10^{\circ} 26^{\prime}$ S, $161^{\circ} 23^{\prime} \mathrm{E}, 142-$ $160 \mathrm{~m}, 1 \mathrm{dd}, \mathrm{MNHN}$.

TYPE LOCALITY. - Loyalty Islands, Lifou, Baie du Santal, Récif Shelter, $20^{\circ} 54^{\prime} \mathrm{S}, 167^{\circ} 02^{\prime} \mathrm{E}, 100-120 \mathrm{~m}$ [ATELIER LIFOU 2000: $\operatorname{stn} 1461]$.

Distribution. - Currently known from New Caledonia, probably living in 10-47 $\mathrm{m}$ and from W San Cristobal, Solomon Islands, dredged dead in 12-142 m.

\section{DESCRIPTION}

Shell large for the subgenus, height up to $11.5 \mathrm{~mm}$ at maturity, height/width ratio 1.7-2.0. Slender, biconical, broadly-ovate, squamous. Subsutural ramp narrow, weakly sloping, weakly concave. Shell white or light tan, occasionally darker coloured P5 or from P5 to tip of siphonal canal, with light brown blotches on subsutural area and above anal notch. Aperture white.

Spire high with 1.5 protoconch whorls (Fig. 1K, L) and up to five broadly convex, weakly angulate, shouldered whorls. Suture of teleoconch whorls 
adpressed. Protoconch large, broad, whorls rounded. Diameter of protoconch (holotype) $700 \mu \mathrm{m}$. Terminal lip thin, weakly raised, almost straight.

Axial sculpture of teleoconch whorls consisting of moderately high, narrow, webbed varices. First whorl with 6 or 7 varices, second to penultimate with 5 or 6 , last whorl with 5 varices. Other axial sculpture of numerous, low, obvious growth lamellae. Spiral sculpture of low, broad, squamous primary cords and narrow, squamous, occasionally shallow secondary cords and threads. First teleoconch whorl with visible $\mathrm{P} 1$ and $\mathrm{P} 2, \mathrm{P} 1$ weaker; 2 nd whorl with P1, s1, P2; 3rd with adis, IP, abis, P1, s1, P2, (P3), s1 similar in strength to $\mathrm{P} 1$; 4 th whorl of subadult paratypes with adis, IP, abis, P1, s1, P2, P3, P4, (s4), P5, (s5), P6, s6, ADP, MP, ABP; last whorl of holotype with adis, IP, abis, P1, s1, P2, P3, P4, P5, P6, ADP, MP, ABP, ads and two or three additional abapical threads; $s 1$ broader than P1, P2-P4 broadest, P5 and next cords decreasing in strength abapically. Presence of several narrow, squamous threads between and on spiral cords. Spiral cords extending on axial varices, forming webbed varices.

Aperture moderately large, narrow, ovate. Columellar lip narrow, with 2 or 3 small denticles abapically; abapical two denticles closely spaced. Rim partially weakly erect, adherent at adapical extremity, with weak or obsolete, low parietal tooth at adapical extremity. Anal notch deep, narrow. Outer lip weakly erect, crenulated, with strong, broad denticles within: ID, D1 (occasionally split), D2-D5. Siphonal canal medium sized, broad, weakly dorsally recurved, open.

Operculum and radula unknown.

\section{REMARKS}

There are 14 species of Pygmaepterys in the tropical Indo-West Pacific. Three of them have only three axial varices on the last teleoconch whorl, two other species are very small and are geographically restricted to South Africa, while another three species live in the vicinity of the Gulf of Aden and Oman. These eight species do not need to be discussed further here because of their very different shell morphology.

Favartia funafutiensis (Hedley, 1899) has a different protoconch morphology, in that it is conical with $2+$ whorls, and weakly and narrowly keeled abapically.

The five remaining species are F. avatea Houart \& Tröndlé, 2008, F. bellini (D’Attilio \& Myers, 1985), F. isabelae Houart \& Rosado, 2008, F. kurodai Nakamigawa \& Habe, 1961 and F. philcloveri (Houart, 1984).

Favartia lifouensis n. sp. differs from $F$ avatea (Fig. 1E, F) in having a more strongly shouldered shell with a more weakly sloping subsutural area, a higher and narrower spire, a comparatively broader protoconch, an adpressed suture instead of the impressed one in $F$. avatea, fewer axial varices, 5 on the last whorl and 6 or 7 on previous whorls in P. lifouensis vs 6 on the last whorl and 7-9 on previous whorls in $F$. avatea, and weaker, more numerous apertural denticles.

It differs from $F$. bellini (Fig. $1 \mathrm{G}, \mathrm{H}$ ) in having a less shouldered and more ovate shell, narrower, more conspicuous and higher spiral cords and a comparatively broader aperture with smaller denticles.

Favartia isabelae, F. kurodai and F. philcloveri also differ in many ways, including shell height and width, and protoconch, spiral sculpture and aperture morphology.

Favartia (Pygmaepterys) circinata n. sp. (Fig. 1I, J, M)

TYPe MATERial. - Holotype (lv) NMMBM 005342.

MATERIAL EXAMINED. — Only known from the holotype.

FIG. 1. - A-D, K-L, Favartia (Pygmaepterys) lifouensis n. sp.; A, B, New Caledonia, Loyalty Islands, Lifou, Baie du Santal, Shelter Reef, ATELIER LIFOU 2000: stn 1461, 2054'S, $167^{\circ} 02^{\prime} \mathrm{E}, 100-120$ m, holotype MNHN 24174, h $11.5 \mathrm{~mm}$; C, D, New Caledonia, Loyalty Islands, Lifou, E of Baie du Santal, Mepinyo, ATELIER LIFOU 2000: stn 1445, 2051'S, 167¹0’E, 10-12 m, paratype MNHN 24176 , h $8.4 \mathrm{~mm}$; K, protoconch of the holotype; L, protoconch of the illustrated paratype; E, F, Favartia (Pygmaepterys) avatea Houart \& Tröndlé, 2008, French Polynesia, Austral Archipelago, Rimatara, BENTHAUS: stn DW2015, 22³8'S, 152 50’W, 250-280 m, holotype MNHN 20172, h 11.2 mm; G, H, Favartia (Pygmaepterys) bellini (D'Attilio \& Myers, 1985), Philippines, paratype SDMNH 83067a,

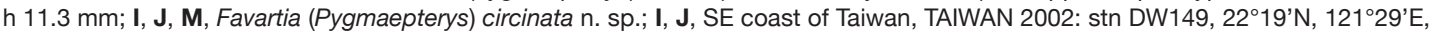
258 m, holotype NMMBM 005342, h 11.6 mm; M, protoconch of the holotype. Scale bars: K-M, $500 \mu \mathrm{m}$. 


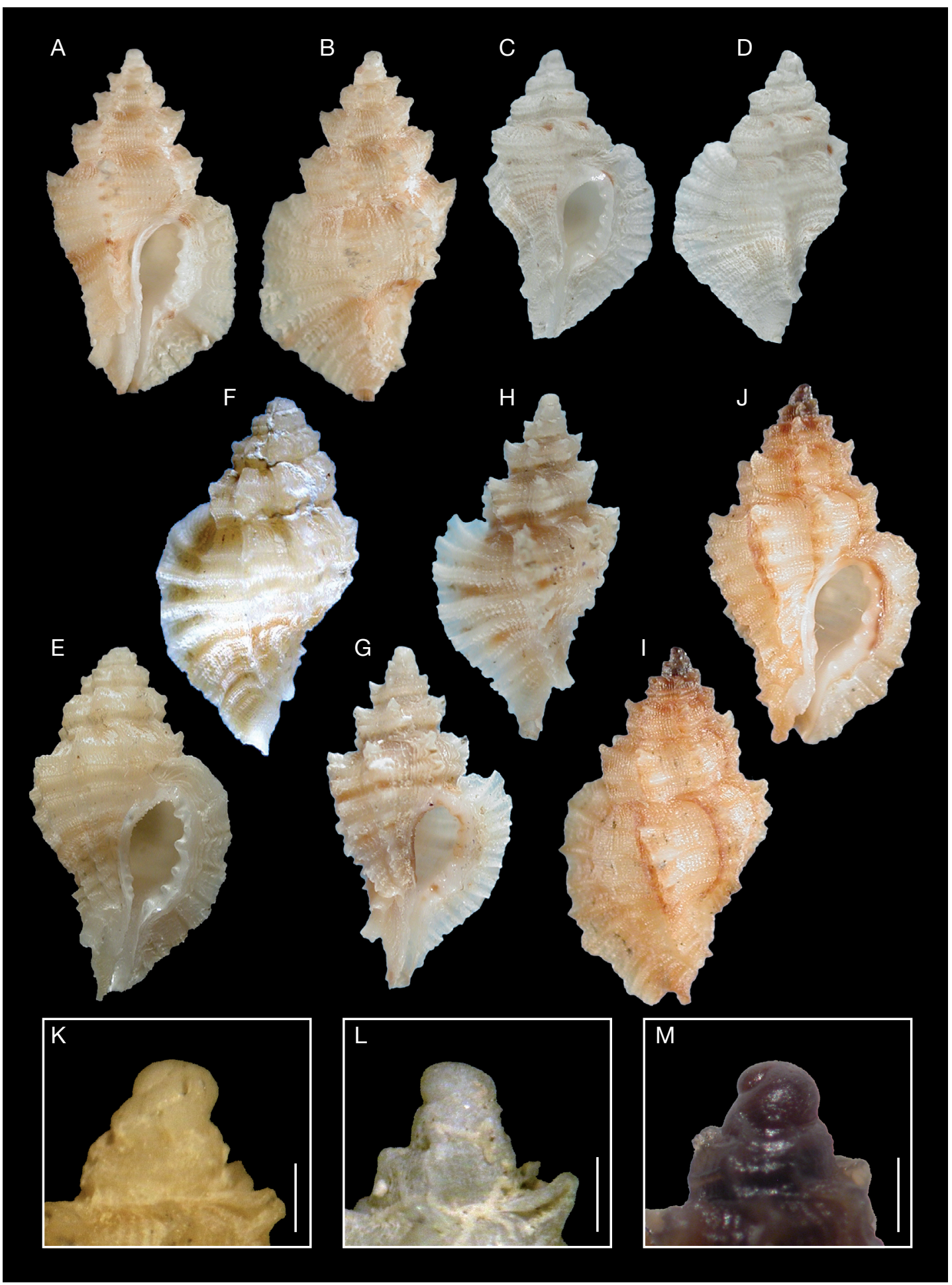


TYPE LOCALITY. - SE coast of Taiwan, $22^{\circ} 19^{\prime} \mathrm{N}, 121^{\circ} 29^{\prime} \mathrm{E}$, $258 \mathrm{~m}$ [NO Ocean Researcher 1, TAIWAN 2002: stn DW149, Chan, Cosel \& Richer-IRD coll., 20/V/2002].

Distribution. - Known only from SE Taiwan at the type locality.

ETYMOLOGY. - From Latin "circinata": rounded, convex, because of the broadly-ovate last teleoconch whorl.

\section{DESCRIPTION}

Shell large for the subgenus, height $11.6 \mathrm{~mm}$ at maturity, height/width ratio 1.7 . Biconical, broadly-ovate, lightly built, weakly squamous. Subsutural ramp narrow, weakly sloping, weakly concave. Protoconch and 1st teleoconch whorl blackish brown, gradually lighter coloured, from greyish brown on 2 nd whorl to light tan on last teleoconch whorl. Outer apertural edge finely surrounded with dark brown line as well as base of axial varices, remnants of previous positions of the aperture. Brown line not extended on siphonal canal. Aperture white within.

Spire high with 1.5 protoconch whorls (Fig. $1 \mathrm{M})$ and five broadly convex, weakly shouldered teleoconch whorls. Suture of teleoconch whorls impressed. Protoconch small, whorls rounded. Diameter $500 \mu \mathrm{m}$. Terminal lip shallow, delicate, weakly curved.

Axial sculpture of teleoconch whorls consisting of low, weak, webbed varices, each with a weak shoulder spine. Other axial sculpture of numerous growth lamellae. Spiral sculpture of low, narrow, squamous primary cords and numerous squamous threads. First to 3rd teleoconch whorls with visible SP, P1 and P2, 4th whorl with SP, P1-P3, last whorl with SP, P1-P5, s5, P6, ADP, MP, ABP and numerous squamous threads on and between spiral cords. Spiral cords extending on varices, forming small, broad, open spinelets joined by squamous webbing, more obvious on high, narrow apertural varix. P2-P5 strongest, P1 weakly narrower and lower, P6 small, narrow, ADP and ABP low, narrow, $\mathrm{MP}$ higher and broader, same strength as $\mathrm{P} 1$.

Aperture moderately large, ovate. Columellar lip narrow with two small knobs abapically. Rim partially weakly erect, adherent at adapical extremity. Anal notch deep, broad. Outer lip weakly erect, smooth, with five strong, broad denticles within:
IP, D1-D2 fused, D3, D4, D5. D1-D2 denticle largest. Siphonal canal short, broad, straight, open. Operculum and radula unknown.

\section{REMARKS}

This species is unique in Pygmaepterys and differs in many ways from all the other known species by its shell morphology and colour. The secondary spiral structure is apparently absent between primary cords P1-P5; however, examination of new material will probably show that some of the threads are in fact secondary cords of the same magnitude as some of the threads.

\section{Genus Murexsul Iredale, 1915}

TYPE SPECIES (by original designation). - Murex octogonus Quoy \& Gaimard, 1832, Recent, New Zealand.

\section{Murexsul merlei Houart \& Héros, 2008 (Figs 4F-I; 5A)}

Murexsul merlei Houart \& Héros, 2008: 454, fig. 4E-G.

Type material. — Holotype (dd) MNHN 20006.

NeW MATERIAl EXAMined (all MNHN). — Coral Sea (new record). EBISCO: stn DW2564, NW Bellona, 202 $5^{\prime} \mathrm{S}, 158^{\circ} 41^{\prime} \mathrm{E}, 333-386$ m, $1 \mathrm{dd}$. - Stn DW2617, Lansdowne, $20^{\circ} 06^{\prime} \mathrm{S}, 160^{\circ} 22^{\prime} \mathrm{E}, 427-505 \mathrm{~m}, 1 \mathrm{dd}$. - Stn DW2632, S Lansdowne, $21^{\circ} 05^{\prime} \mathrm{S}, 160^{\circ} 45^{\prime} \mathrm{E}, 297-378 \mathrm{~m}$, $1 \mathrm{lv}$ (SEM of the radula, Fig. 5A). - Stn CP2640, $20^{\circ} 46^{\prime} \mathrm{S}, 160^{\circ} 58^{\prime} \mathrm{E}, 300-319 \mathrm{~m}, 1 \mathrm{lv}, 1 \mathrm{dd}$ (Fig. 4F-I). Vanuatu (new record). MUSORSTOM 8: stn DW967, $20^{\circ} 19^{\prime} \mathrm{S}, 169^{\circ} 53^{\prime} \mathrm{E}, 295-334 \mathrm{~m}, 1 \mathrm{dd}$.

Type LOCALITY. - Tonga, N Ha’apai group, $19^{\circ} 03^{\prime} \mathrm{S}$, $174^{\circ} 19^{\prime} \mathrm{W}, 523-806$ m [BORDAU 2: stn DW1595].

Distribution. - Tonga, Fiji, Coral Sea, and Vanuatu, living in 314-319 m, empty shells in 319-523 m. Murexsul merlei was previously known from the holotype and 2 paratypes, described from Tonga and Fiji, dredged alive at 314-377 m. The bathymetric range in Coral Sea for living specimens is similar to that recorded in Fiji.

\section{REMARKS}

The colour of the Coral Sea material is similar to that of the holotype, having the protoconch and 
the first teleoconch whorl light brown and the tip of the siphonal canal dark brown. The shell from Vanuatu is $19 \mathrm{~mm}$ in height, while the largest shell examined from Tonga (holotype) is only $14.6 \mathrm{~mm}$ in height.

The radula (Fig. 5A) was not previously illustrated and is typical for the muricopsine subfamily with a short central projecting cusp, two long lateral denticles situated between the central and lateral cusps, and short marginal cusps.

\section{Genus Pazinotus Vokes, 1970}

Type SPECIES (by original designation). - Eupleura stimpsonii Dall, 1889, Recent, western Atlantic.

\section{Pazinotus brevisplendoris (Houart, 1985)}

(Fig. 2J)

Poirieria (Pazinotus) brevisplendoris Houart, 1985: 163, figs 6, 6B.

Type Material. - Holotype (dd) MNHN 1040.

New Material EXAmined. - Solomon Islands (new record). SALOMON 1: stn DW1758, 849'S, 159 52'E, 180-187 m, 1 dd (MNHN).

TYPE LOCALITY. - Northeastern Madagascar, 2051'S, 553'ㄹ, 290-300 m [MD32 REUNION: stn CP129].

Distribution. - Mozambique, northeastern Madagascar and Solomon Islands, bathymetric range unknown for living specimens, empty shells in 187-290 m.

\section{REMARKS}

Pazinotus brevisplendoris was described from Mozambique and had not been recorded subsequently from any other locality. The specimen collected in the Solomon Islands was an empty shell, weakly damaged and faded, of a light tan colour. The colour of $P$. brevisplendoris from Mozambique is reddish-brown or light pink. Pazinotus brevisplendoris differs from P. smithi (Schepman, 1911), known only from the holotype collected in the Philippines, in having a last teleoconch whorl that is broader compared to the early whorls than in $P$. smithi, in having less adapically recurved shoulder spines and in having a different spiral cord morphology, narrower primary cords and a less smooth shell with secondary spiral cords or numerous striae vs smooth in $P$. smithi. The primary spiral sculpture in $P$. smithi consists of smooth, low and broad P1-P6 only vs P1, P2, (S2), P3, P4, P5, s5, P6, ADP in P. brevisplendoris with more closely spaced but relatively narrower P5, P6 and ADP.

\section{Pazinotus chionodes $\mathrm{n}$. sp.}

(Fig. 2A, B, M)

TyPe MATERIAL. - Holotype (dd) MNHN 24178 and 1 paratype (dd) MNHN 24179.

Material EXAMined. - Only known from the type material.

Type locality. - Coral Sea, off New Caledonia, S Lansdowne, 2047'S, $161^{\circ} 01^{\prime} \mathrm{E}, 289-294 \mathrm{~m}$ [EBISCO: stn DW2639, Bouchet, Lozouet, Warén, Richer-IRD coll., 22/X/2005].

Distribution. - Known only from the Coral Sea at the type locality.

ETymology. - From ancient Greek "chionodes": snow white.

\section{DESCRIPTION}

Shell medium sized for the genus, holotype $10.1 \mathrm{~mm}$ in height, height/width ratio 1.41. Broadly-ovate, lightly built. Subsutural ramp weakly sloping on early whorls, more strongly sloping on last whorl, especially between penultimate and last (apertural) varix, weakly convex. Shell entirely white.

Spire high with 1.5 protoconch whorls (Fig. 2M) and teleoconch of 4.5 broad, convex, strongly shouldered whorls. Protoconch small, whorls rounded, smooth, glossy. Diameter (holotype) $600 \mu \mathrm{m}$. Terminal lip delicate, thin, weakly curved.

Axial sculpture of teleoconch whorls consisting of high, narrow, broadly lamellate varices, each with broad, open shoulder spine. Last (apertural) varix shoulder spine broader, long. Preceding varices with narrowly open shoulder spine. Abapical spines long, very broad, connected to each other with narrow, broadly expanded lamellar flange, 
extending from last varix of preceding whorl to tip of siphonal canal. Last whorl with four varices, early whorls with five. Spiral sculpture of low, very weak, narrow, smooth primary and secondary cords. First teleoconch whorls with visible weakly defined P1 ending as lightly adapically bent shoulder spine. P2 more weakly defined, occasionally with very weak s1 between P1 and P2. Spiral sculpture of last whorl with weak, narrow, low P1-P6 and ADP, MP, ABP. Spiral sculpture occasionally more apparent on abapertural side of lamellate varices. Very weak, quite indiscernible, irregular, secondary cords.

Aperture large, ovate. Columellar lip narrow with three strong knobs abapically. Last abapical knob high and strong. Rim weakly detached abapically. Anal notch shallow, broad. Outer lip erect, smooth, with weak IP and five strong denticles within: D1-D5; D1 strongest, D3-D4 weakest, D2 and D5 of approximately similar strength. Siphonal canal short, broad, dorsally recurved at tip (partially broken in both specimens examined), narrowly open.

Operculum and radula unknown.

\section{REMARKS}

There are six known Recent species of Pazinotus in the tropical Indo-West Pacific: P. brevisplendoris (Houart, 1985), P. falcatiformis (Thiele, 1925), P. kilburni (Houart, 1987), P. sibogae (Schepman, 1911), P. smithi (Schepman, 1911) and P. spectabilis Houart, 1991. None of these is particularly close to $P$. chionodes $\mathrm{n}$. sp. except $P$. falcatiformis (Fig. $2 \mathrm{~K}$, $\mathrm{L})$, which differs from $P$. chionodes $\mathrm{n}$. sp. in having a more triangular outline, a less expanded varical flange, 5 lamellate varices on the last teleoconch whorl, and in having a comparatively narrower aperture.

\section{Pazinotus falcatiformis (Thiele, 1925)}

(Fig. 2K, L)

Murex falcatiformis Thiele, 1925: 168, pl. 18, fig. 10.

Type Material. - Holotype dd, ZMB.

NEW MATERIAL EXAMINED (all MNHN). - Solomon Islands (new record). SALOMON 2: stn DW2234, Choiseul Island, Oldham Deep, 6 6 51'S, 156 24'E, 182-277 m, 1 dd. - SALOMONBOA 3: stn CP2809, E Malaita, 9¹9'S, $161^{\circ} 27^{\prime} \mathrm{E}, 788-1042 \mathrm{~m}, 1$ dd (Fig. 2K, L).

Type LOCALity. - North of Nias Island, Sumatra, Indonesia, $1^{\circ} 48^{\prime} \mathrm{N}, 97^{\circ} 6^{\prime} \mathrm{E}, 141 \mathrm{~m}$.

Distribution. - Indonesia, Philippines (Houart 2008), Fiji (Houart \& Héros 2008) and Solomon Islands, living in 290-300 m (Houart \& Héros 2008), shells in 141-788 m.

\section{REMARKS}

Pazinotus falcatiformis was described from Indonesia. Other specimens are known from Aliguay Islands, Sulu Sea, Philippines (Houart 2008), Fiji (Houart \& Héros 2008) and now the Solomon Islands. The holotype is larger but with more numerous teleoconch whorls, it also has longer, more acute shoulder spines than in other examined material, but other shell characters (paucispiral protoconch, angulate aperture, spines connected by a broad webbing, number of varices, ontogeny and morphology of the spiral cords) are similar to those of specimens from the other localities.

\section{Subfamily TRIPTEROTYPHINAE \\ D’Attilio \& Hertz, 1988}

Genus Prototyphis Ponder, 1972

TYPE SPECIES (by original designation). - Typhis angasi Crosse, 1863, Recent, Australia.

FIG. 2. - A, B, M, Pazinotus chionodes n. sp.; A, B, New Caledonia, S Lansdowne Bank, EBISCO: stn DW2639, 2047'S, $161^{\circ} 01^{\prime} \mathrm{E}$, 289-294 m, holotype MNHN 24178, h 10.1 mm; M, protoconch of the holotype; C, D, N, Gemixystus calcareus n. sp.; C, D, Chesterfield Reefs, EBISCO: stn DW2603, 19³6'S, 158 43 'E, 568-570 m, holotype MNHN 24180, h 5.4 mm; N, three views of the protoconch of the holotype; E, Gemixystus stimuleus (Hedley, 1907), Australia, New South Wales, Sydney, $35 \mathrm{~km}$ E of Narrabeen, 146 m, holotype AMS C25797, h 3.3 mm; F, Gemixystus rippingalei (Houart, 1998), Australia, Queensland, E of Lady Musgrave Island, paratype coll. RH, h 3.7 mm; G, Gemixystus leptos (Houart, 1995), South New Caledonia, 230-290 m, coll. RH, h 5.1 mm; H, I, Ponderia magna Houart, 1988, Coral Sea, Chesterfield Plateau, EBISCO: stn DW2612, 19³5'S, 15841'E, 392 m, MNHN, h 19.6 mm; J, Pazinotus brevisplendoris Houart, 1985, Solomon Islands, SALOMON 1: stn DW1758, 849'S, $159^{\circ} 52^{\prime} \mathrm{E}, 180-187 \mathrm{~m}, \mathrm{MNHN}$, h 14.4 mm; K, L, Pazinotus falcatiformis (Thiele, 1925), Solomon Islands, E Malaita, SALOMONBOA 3: stn CP2809, 09¹9' S, 161²7’'E, 788-1042 m, MNHN, h $7.1 \mathrm{~mm}$. Scale bars: M, N, $500 \mu \mathrm{m}$. 


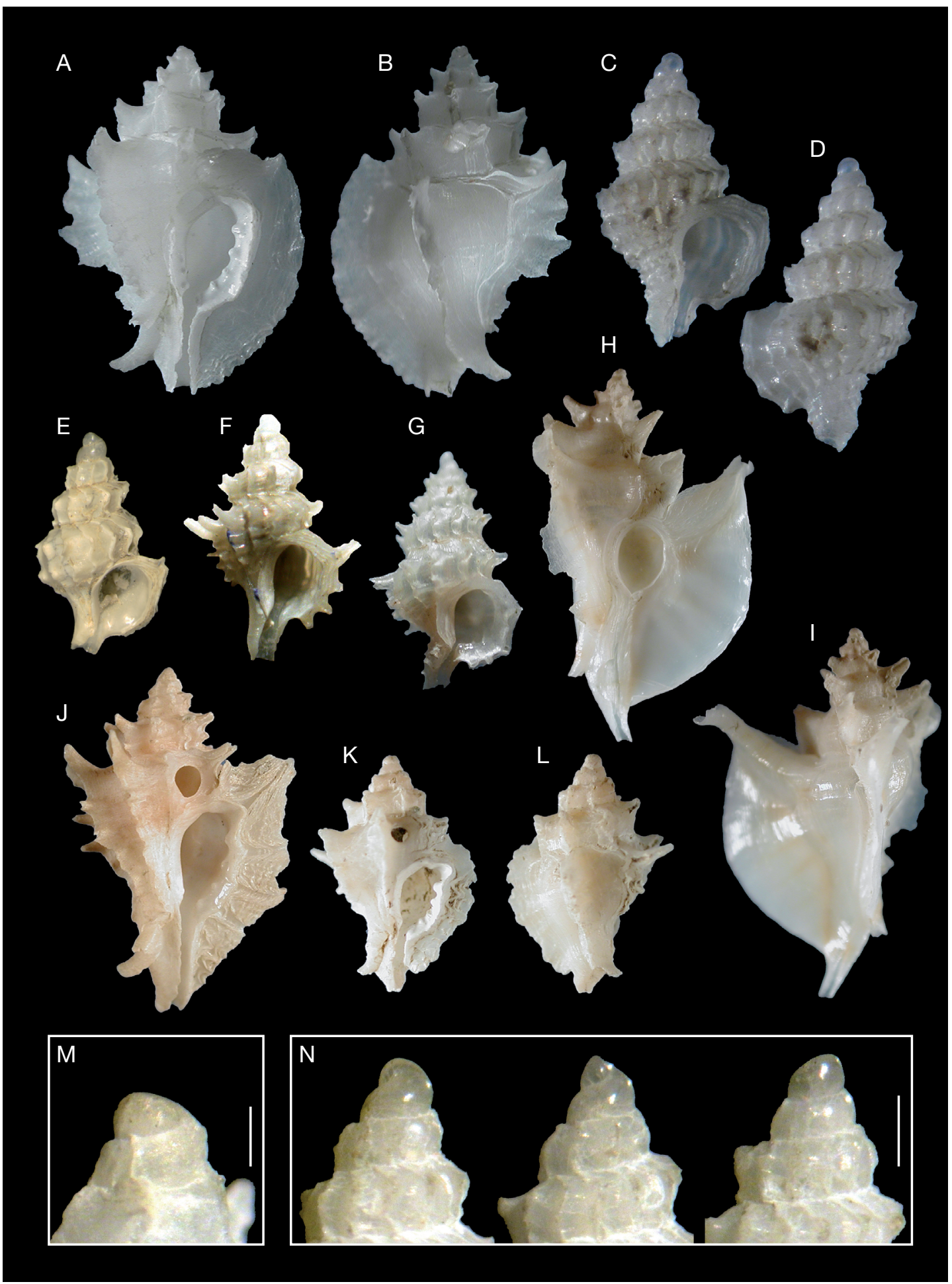




\section{Prototyphis gracilis Houart \& Héros, 2008} (Fig. 4D, E)

Prototyphis gracilis Houart \& Héros, 2008: 473, fig. 7B-E.

TyPe MATERial. - Holotype (dd) MNHN 20010.

New Material EXamined. - Coral Sea (new record). EBISCO: stn DW2496, Capel Bank, 2446' S, 15943'E, 400-418 m, 1 dd (MNHN).

Type locality. - Fiji, Somosomo Strait, 16²'S, 17959’E, 416 m [BORDAU 1: stn CP1394].

Distribution. - Coral Sea and Fiji, bathymetric range unknown for living specimens, empty shells in 416-418 m.

\section{REMARKS}

The shell collected in Coral Sea is considerably larger than the $23.5 \mathrm{~mm}$ holotype from Fiji, until now the only specimen known. This specimen is $32.8 \mathrm{~mm}$ high with a badly broken siphonal canal. However, it has one or probably 1.5 teleoconch whorls more than the holotype, which explains this large size. It is otherwise similar to the holotype although with a slightly weaker axial sculpture on the last teleoconch whorl.

\section{Genus Ponderia Houart, 1986}

TYPE SPECIES (by original designation). — Typhis zealandica Hutton, 1873, fossil and Recent, New Zealand.

\section{Ponderia magna Houart, 1988} (Fig. $2 \mathrm{H}, \mathrm{I}$ )

Ponderia magna Houart, 1988: 192, figs 11, 12, 20.

Type MATERIAL. - Holotype (dd) MNHN 0210.

NEW MATERIAL EXAMINED (all MNHN). — Coral Sea. EBISCO: stn DW2606, Chesterfield Reefs, 19³6'S, $158^{\circ} 42^{\prime} \mathrm{E}, 442-443 \mathrm{~m}, 2 \mathrm{dd}$. - Stn DW2607, $19^{\circ} 33^{\prime} \mathrm{S}$, 158 40 'E, 400-413 m, 1 lv \& 3 dd. - Stn DW2609, $19^{\circ} 33^{\prime} \mathrm{S}, 158^{\circ} 40^{\prime} \mathrm{E}, 431-436 \mathrm{~m}, 1 \mathrm{dd}$. - Stn DW2612, $19^{\circ} 35^{\prime} \mathrm{S}, 158^{\circ} 41^{\prime} \mathrm{E}, 392 \mathrm{~m}, 1$ lv, 1 dd (Fig. 2H, I).

Type LOCALITY. - Coral Sea, Chesterfields Reefs, $355 \mathrm{~m}$, $19^{\circ} 54^{\prime} \mathrm{S}, 158^{\circ} 38^{\prime} \mathrm{E}$ [MUSORSTOM 5: stn DC378].

Distribution. - Coral Sea, Chesterfield Reefs, living in 392-410 m, empty shells in 355-431 m.

\section{REMARKS}

These are the first records of Ponderia magna since its description. The coordinates and depth are quite similar to those of the original material which was also collected in the Coral Sea, Chesterfield Reefs, during the MUSORSTOM 5 cruise.

\section{Subfamily Trophoninae Cossmann, 1903}

\section{REMARKS}

The subfamily Trophoninae is polyphyletic, based on molecular data, with the genus Leptotrophon Houart, 1995 correctly placed in the Trophoninae (Barco et al. 2010). However, Gemixystus Iredale, 1929 and Scabrotrophon McLean, 1996 have not yet been included in phylogenetic analyses and are here included conservatively in Trophoninae, pending future phylogenetic study.

\section{Genus Gemixystus Iredale, 1929}

Type species (by original designation). - Trophon laminatus Petterd, 1884, Recent, southeastearn Australia.

Apixystus Iredale, 1929 (type species by original designation: Trophon stimuleus Hedley, 1907, Recent, eastern Australia).

\section{REMARKS}

Iredale (1929: 185) separated Gemixystus from Apixystus because of their different protoconch morphology, Gemixystus having an "angulate apex" compared to the "smooth rounded apex" of Apixystus. However, such differences in Muricidae are now considered to be a useful tool at the specific level only. The two taxa were recognized as congeneric by Houart (2004).

\section{Gemixystus calcareus n. sp.}

(Fig. 2C, D, N)

Type Material. - Holotype (dd) MNHN 24180.

Material EXAmined. - Only known from the holotype.

TyPe LoCality. - Coral Sea, Chesterfield Reefs, $19^{\circ} 36^{\prime}$ S, 15843’E, 568-570 m [EBISCO: stn DW2603, Bouchet, Lozouet, Warén, Richer-IRD coll., 18/X/2005]. 
Distribution. - Known only from the Chesterfield Reefs at the type locality.

ETYмology. - From Latin "calcareus": chalk-white.

\section{DESCRIPTION}

Shell medium-sized for the genus, height $5.4 \mathrm{~mm}$, height/width ratio 1.7. Broadly-ovate, lightly built, lamellate. Subsutural ramp narrow, weakly sloping, weakly convex. Shell entirely chalk-white.

Spire high with 1.6 protoconch whorls (Fig. 2N) and 4.2 broad, weakly shouldered teleoconch whorls. Suture of teleoconch whorls impressed, partially obscured by small axial lamellae of following whorl. Protoconch comparatively large, broad, weakly acuminate with broad keel adapically, otherwise smooth. Diameter $500 \mu \mathrm{m}$. Terminal lip delicate, thin, weakly curved.

Axial sculpture of teleoconch whorls consisting of low, narrow, frilled lamellae, each with short, broad, open spinelets occurring at crossings of axial lamellae with spiral cords. Spines more conspicuous on P1. First whorl with 8 lamellae, 2nd with 13, 3rd with 16 and 4th with 20. Apertural lamella strongly erect, broad. Spiral sculpture of low, broad, rounded primary cords: P1-P3 visible on 1st to 3rd whorl with slightly visible, very narrow $\mathrm{P} 2$. P3 partially covered by following whorl. Last teleoconch whorl with P1-P5, ADP, MP. P1P5 equidistant, P1 slightly larger, P2 narrow. ADP and MP narrower, MP low.

Aperture broad, rounded. Columellar lip narrow, smooth. Lip adherent at adapical extremity. Anal notch obsolete. Outer lip strongly erect with five weak, elongate denticles within: D1-D5. D4 and D5 narrower, more strongly elongate within. Siphonal canal short, narrow, straight, open, with ADP and MP and low axial lamellae over whole length.

\section{REMARKS}

The genus Gemixystus was revised by Houart (2004) and contains six fossil and eight Recent species.

None of the fossil species is closely related to the new species and of the eight Recent species, only three need to be compared here: Gemixystus leptos (Houart, 1995) from southern Queensland, Australia, to the Chesterfield Reefs, Gemixystus rippingalei
(Houart, 1998) from Queensland, Australia, and Gemixystus stimuleus (Hedley, 1907), from southern Queensland and Sydney, New South Wales, Australia, type species of Apixystus.

Gemixystus calcareus n. sp. differs from the quite similar G. stimuleus (Fig. 2E) in having a comparatively larger shell with twice as large a protoconch, more numerous axial lamellae, 20 vs 11 or 12 on last whorl and 16 vs $13-15$ on penultimate whorl. The spiral sculpture also differs, G. calcareus n. sp. having P1-P5, ADP and MP on last teleoconch whorl vs P1-P3 in G. stimuleus, which has no spiral sculpture on the siphonal canal.

Gemixystus calcareus n. sp. also differs from $G$. rippingalei (Fig. 2F) in having a comparatively larger shell, $G$. rippingalei reaching only $4.4 \mathrm{~mm}$ in height and having a longer siphonal canal, a less spiny shell and a different spiral sculpture morphology, that is, a last whorl with closely spaced P1-P4 and a smooth siphonal canal.

Finally, G. calcareus n. sp. differs from $G$. leptos (Fig. 2G) in having a comparatively broader, but otherwise similar protoconch, a less shouldered and less spiny shell with more numerous axial lamellae, 20 vs 10 or 11 on 4th whorl and 16 vs 11 on penultimate whorl, while having fewer lamellae on first whorl, 8 vs 10 or 11 in G. leptos. The spiral sculpture morphology also differs, $G$. leptos having two broad, broadly spaced P1 and P2 and two small, narrow, closely spaced P3 and P4. The siphonal canal is smooth in $G$. leptos or with a very shallow and narrow MP only.

\section{Genus Leptotrophon Houart, 1995}

TYPE SPECIES (by original designation). - Leptotrophon caroae Houart, 1995, Recent, New Caledonia.

\section{Leptotrophon minirotundus}

(Houart, 1986) n. comb.

(Fig. 3K)

Trophon (Trophonopsis) minirotundus Houart, 1986: 438, figs 4, 4a-b.

Type MATERial. - Holotype (dd) MNHN 24616. 
NeW MATERIAL EXAMINED (all MNHN). - New Caledonia. BATHUS 3: stn DW836, Norfolk Ridge, 2302'S, 166 59'E, 295-306 m, 1 dd. - Stn DW838, Norfolk Ridge, $23^{\circ} 01^{\prime} \mathrm{S}, 166^{\circ} 56^{\prime} \mathrm{E}, 400-402 \mathrm{~m}, 1 \mathrm{dd}$.

Type locality. - New Caledonia, 2230'S, $166^{\circ} 24^{\prime} \mathrm{E}$, 250-350 m.

Distribution. - New Caledonia, bathymetric range unknown for living specimens, empty shells in $306-400 \mathrm{~m}$.

\section{REMARKS}

Examination of additional and more mature material since the original description and comparison with the type species and other species of Leptotrophon leads us to place Trophon minirotundus in Leptotrophon based solely on shell characters. The species has never been collected alive.

\section{Leptotrophon wareni $\mathrm{n}$. sp.}

(Fig. 3A-D)

TYPE MATERIAL. - Holotype (dd) MNHN 24181 and 3 paratypes (dd) MNHN 24182-24184.

TYPE LOCALITY. - Solomon Islands, $8^{\circ} 16$ 'S, $160^{\circ} 40^{\prime} \mathrm{E}$, 570-756 m [NO Alis, SALOMON 1: stn DW1772, Bouchet, Dayrat, Warén \& Richer-IRD coll, 28/IX/2001].

MATERIAL EXAMINED. - Solomon Islands. SALOMON 1: stn DW1772, 8¹6'S, 16040'E, 570-756 m, 1 dd, holotype MNHN 24181. - Stn DW1824, 949's, $160^{\circ} 56^{\prime} \mathrm{E}, 298-318 \mathrm{~m}, 1 \mathrm{dd}$, paratype MNHN 24182. Stn DW1825, 9 $51^{\circ} \mathrm{S}, 160^{\circ} 58^{\prime} \mathrm{E}, 340-391 \mathrm{~m}, 1 \mathrm{dd}$, paratype MNHN 24183. - SALOMONBOA 3: stn DW2790, N Malaita, 8¹9'S, 160³7’E, 314-586 m, $1 \mathrm{dd}$, paratype MNHN 24184.

Distribution. - Solomon Islands, known only from the four stations listed above, empty shells in $318-570 \mathrm{~m}$.

ETymology. - Named in honour of Anders Warén (Swedish Museum of Natural History, Stockholm), in recognition of his collaboration over many years in extracting, mounting and scanning hundreds of muricid radulae and shells for analysis of microsculpture.

\section{DESCRIPTION}

Shell medium sized for the genus, height $11.8 \mathrm{~mm}$, height/width ratio 2-2.4. Slender, lanceolate, narrow, nodose. Subsutural ramp broad, strongly sloping, weakly concave. Shell entirely white.

Spire very high with 1.5 protoconch whorls (Fig. 3D) and five angulate, narrow, shouldered, nodose whorls. Suture weakly adpressed. Protoconch large, broad, whorls rounded, smooth. Diameter (holotype) $900 \mu \mathrm{m}$. Terminal lip shallow, weakly curved.

Axial sculpture of teleoconch whorls consisting of low, broad, rounded varices, each with short, blunt spinelets. First teleoconch whorl with 8 or 9 varices, 2 nd with $6-8,3$ rd with 7 or 8 , 4 th and 5 th (last) with 7. Spiral sculpture of low, broad primary cords. First to antepenultimate whorl with visible P1 and P2, penultimate (4th) whorl with P1, P2 and P3; P3 partially covered with following whorl. Last whorl with weakly defined IP, most conspicuous on axial varices, P1, P2, s2, P3-P6, ADP, MP, ABP, EABP1 (EABP2, EABP3) (Fig. 3C). Spiral cords decreasing in strength and more closely spaced abapically. Intersection of axial varices and spiral cords with small, strong, blunt spinelets. P1 and P2 with strongest spines. Other spiral sculpture consisting of numerous, narrow striae.

Aperture small, ovate. Columellar lip narrow, smooth, rim adherent. Anal notch shallow, broad. Outer lip erect, smooth within. Siphonal canal short, narrow, weakly dorsally recurved, open.

Operculum and radula unknown.

\section{REMARKS}

The genus Leptotrophon currently includes 28 Recent species, a majority of them (25) described from New Caledonia and neighbouring localities. One species was

FIG. 3. - A-D, Leptotrophon wareni n. sp.; A, B, Solomon Islands, SALOMON 1: stn DW1772, 8¹6'S, 16040’E, 570-756 m, holotype MNHN 24181, h $11.8 \mathrm{~mm}$; C, spiral cords morphology; D, two views of the protoconch; E, F, Leptotrophon minispinosus Houart, 1995, New Caledonia, MUSORSTOM 4: stn DW184, 1904'S, 1632ㄱㄹㅡ, 260 m, paratype coll. RH, h 11.1 mm; G, H, Leptotrophon segmentatus (Verco, 1909), South Australia, $65 \mathrm{~km} \mathrm{~S}$ of Cape Wiles, 174-183 m, coll. RH, h $8.5 \mathrm{~mm}$; I, J, Leptotrophon coralensis

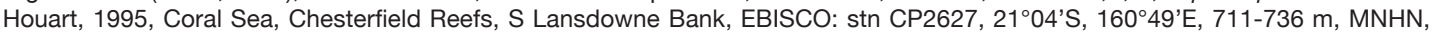
h 7.3 mm; K, Leptotrophon minirotundus Houart, 1985, New Caledonia, BATHUS 3: stn DW836, 2302'S, 16659'E, 295-306 m, MNHN, h 6.5 mm; L, M, Scabrotrophon inspiratum Houart, 2003; L, Solomon Islands, SALOMON 1: stn CP1781, $8^{\circ} 31^{\prime} \mathrm{S}, 1^{\prime 6} 0^{\circ} 38^{\prime} \mathrm{E}$, 1036-1138 m, MNHN, h 36.4 mm; M, Solomon Islands, S Malaita, SALOMONBOA 3: stn CP2817, 955'S, 161³3’E, 1136-1750 m, MNHN, h $38.9 \mathrm{~mm}$. Scale bars: C, $1000 \mu \mathrm{m}, \mathrm{D}, 500 \mu \mathrm{m}$. 
New species of Muricidae (Gastropoda) from the western Pacific
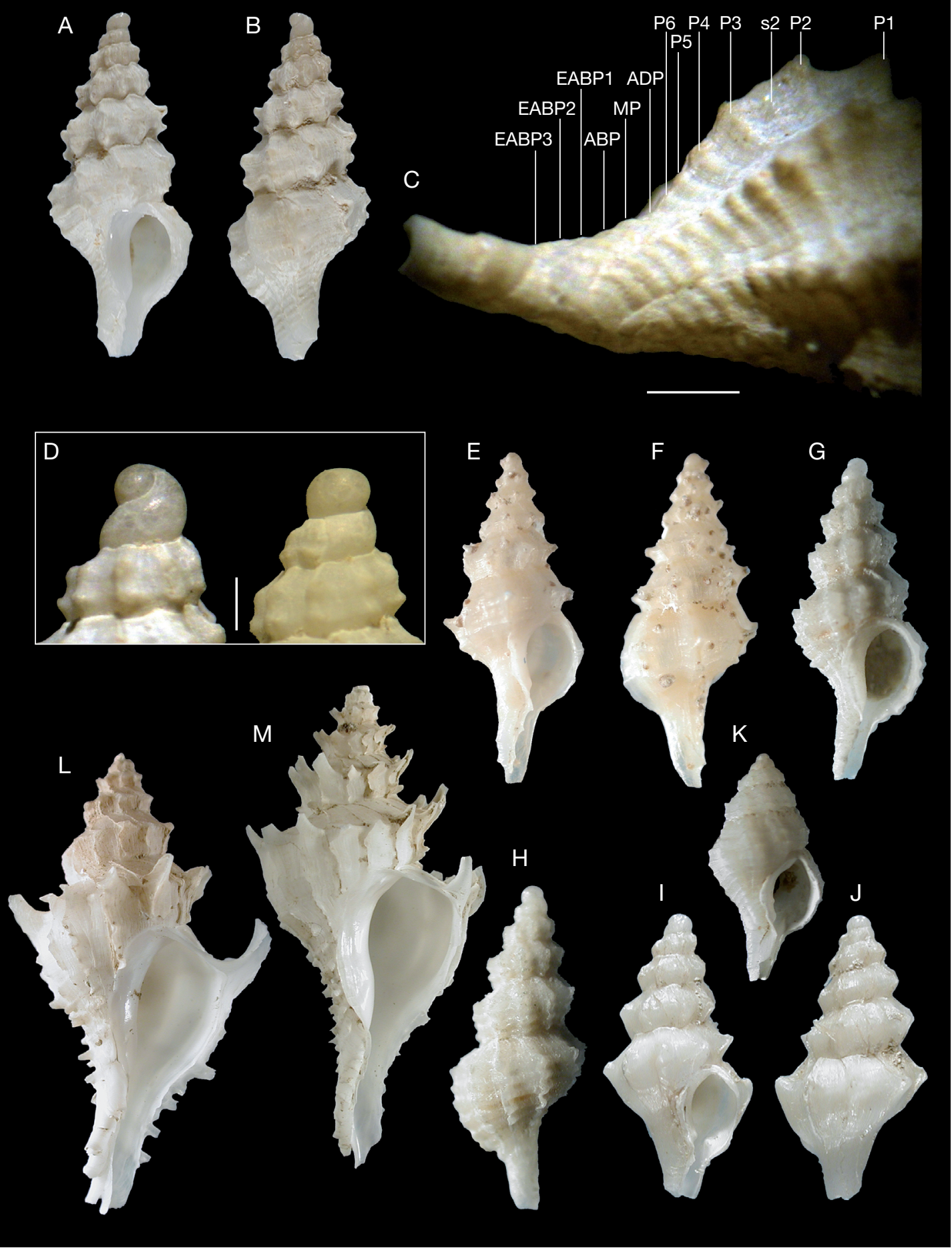

ZOOSYSTEMA • $2012 \bullet 34(1)$

33 
described from Indonesia, and another from Brazil. Leptotrophon segmentatus (Verco, 1909) (Fig. 3G, H) from South Australia is here included for the first time in Leptotrophon, based on shell morphology.

Leptotrophon wareni n. sp. can be usefully compared with only three species: L. segmentatus, L. coralensis Houart, 1995 and L. minispinosus Houart, 1995. All other species differ in many distinct ways.

Leptotrophon wareni $\mathrm{n}$. sp. differs from L. segmentatus in having a narrower shell with a less acute spire, more widely spaced and lower spiral cords, more numerous and narrower spiral cords on the siphonal canal, and an aperture with adherent inner lip, contrasting with the widely flaring lip of $L$. segmentatus.

It differs from L. coralensis (Fig. 3I, J) and L. minispinosus (Fig. 3E, F), two species also with very high spires, in having a more nodose, less shouldered shell, broader axial varices, and in having more numerous visible spiral cords on early teleoconch whorls, L. coralensis and L. minispinosus having only one visible spiral cord (P1) from 1 st to 4 th teleoconch whorls in adult specimens, while the subsutural ramp in these species is also broader and more strongly sloping.

\section{Leptotrophon coralensis Houart, 1995} (Fig. 3I-J)

Leptotrophon coralensis Houart, 1995: 483, figs 70, 71, $120,121$.

Type Material. - Holotype (dd) MNHN 1022.

New Material eXamined. - Coral Sea. EBISCO: stn CP2627, Chesterfield Reefs, S Lansdowne, $21^{\circ} 04^{\prime} S$, 16049'E, 711-736 m, 1 dd (MNHN).

TYPE LOCALITY. - Lansdowne-Fairway Ridge, $21^{\circ} 01^{\prime} \mathrm{S}$, $160^{\circ} 57^{\prime} \mathrm{E}$, 650-660 m [CORAIL 2: stn DE14].

Distribution. - Coral Sea, Chesterfields Reefs, bathymetric range for living specimens unknown, empty shells in 660-711 m.

\section{REMARKS}

This is the first record of Leptotrophon coralensis since its description and the second known specimen. It seems to be one of the rarest species of Leptotrophon from New Caledonia. The coordinates and depth are quite similar to those of the original material, which was also collected in the Coral Sea, Chesterfield Reefs at $21^{\circ} 01^{\prime} \mathrm{S}, 160^{\circ} 57^{\prime} \mathrm{E}$, in $650-660 \mathrm{~m}$. The holotype and this additional specimen were both dead collected. The additional specimen closely matches the original description but due to its broken siphonal canal is not as high as the holotype, the height of which is $9.5 \mathrm{~mm}$.

\section{Genus Scabrotrophon McLean, 1996}

TyPe SPECIES (by original designation). - Trophon maltzani Kobelt \& Küster, 1878, northeastern Pacific.

\section{Scabrotrophon inspiratum Houart, 2003}

(Figs 3L, M; 5B)

Scabrotrophon inspiratum Houart, 2003: 87, figs 1, 3-7.

TyPe MATERIAL. - Holotype (dd) MNHN 3632.

NeW MATERIAl EXAMINEd (all MNHN). - Solomon Islands (new record). SALOMON 1: stn CP1764, 8³7'S, $160^{\circ} 1^{\prime} \mathrm{E}, 1327-1598 \mathrm{~m}, 1 \mathrm{dd}$ (juv.). - Stn CP1781, $8^{\circ} 31^{\prime} \mathrm{S}, 160^{\circ} 38^{\prime} \mathrm{E}, 1036-1138 \mathrm{~m}, 1 \mathrm{lv}, 1 \mathrm{dd}$ (juv.) (Fig. 3L). - SALOMON 2: stn CP2189, SE Santa Isabel Island, $8^{\circ} 20^{\prime} \mathrm{S}, 160^{\circ} 2^{\prime} \mathrm{E}, 660-854 \mathrm{~m}, 1 \mathrm{dd}$. - Stn CP2230,

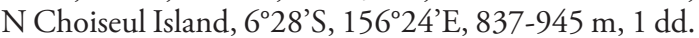
— SALOMONBOA 3: stn CP2817, S Malaita, 955'S, 1613'ㄹ, 1136-1750 m, 1 lv (Fig. 3M).

TYPe LOCAliTY. - Vanuatu, $14^{\circ} 49^{\prime} \mathrm{S}, 167^{\circ} 15^{\prime} \mathrm{E}$, NE of Espiritu Santo Island, 1360 m [MUSORSTOM 8: stn CP1110].

Distribution. - Vanuatu, dead collected in $1360 \mathrm{~m}$ and Solomon Islands, living specimens in $1136-1138 \mathrm{~m}$, empty shells in 854-1327 m. The present records extend

FIG.4. - A, B, Murex (Promurex) protocrassus Houart, 1990, Coral Sea, Capel bank, EBISCO: stn CP2492, 2444'S, 15941'E, 285 m, MNHN, h $63.1 \mathrm{~mm}$; C, Murex (Promurex) spinicosta Bronn, 1831, Piacenza, Italy, Lugagnano, Lower Pliocene, coll. RH, h 33.2 mm; D, E, Prototyphis gracilis Houart \& Héros, 2008; D, Coral Sea, Capel bank, EBISCO: stn DW2496, 2446'S, $159^{\circ} 43^{\prime} \mathrm{E}, 400-418$ m, MNHN, h 32.6 mm; E, Fiji, Somosomo Strait, BORDAU 1: stn CP1394, 1645'S, 17959'E, 416 m, holotype MNHN 20010, h 23.5 mm; F-I, Murexsul merlei Houart \& Héros, 2008; F, G, Coral Sea, S Lansdowne Bank, EBISCO: stn DW2640, 2046'S, 16058'E, 300-319 m, MNHN, h $18.2 \mathrm{~mm} ; \mathbf{H}$, two views of the protoconch; I, operculum. Scale bars: H, I, $500 \mu \mathrm{m}$. 


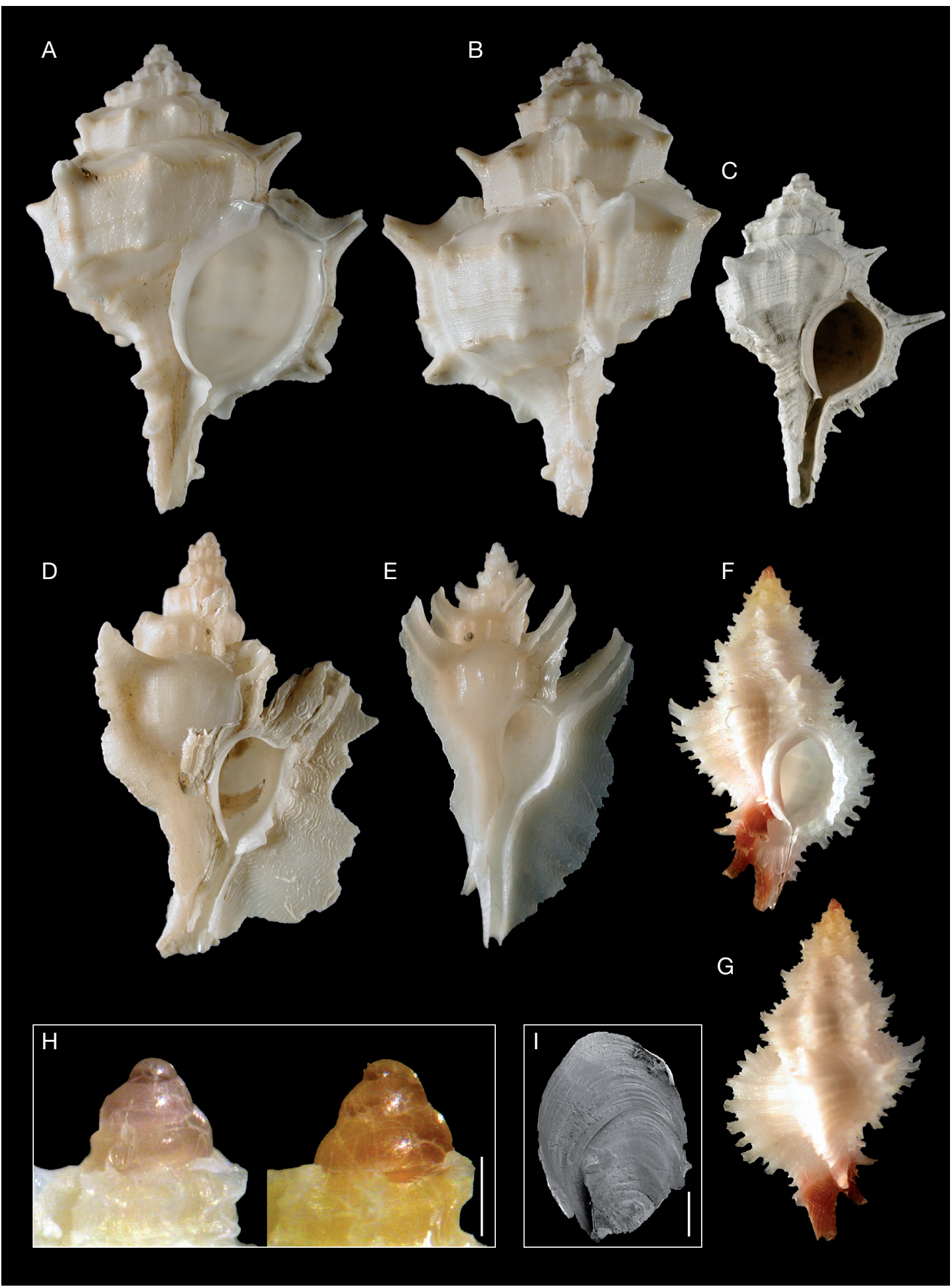



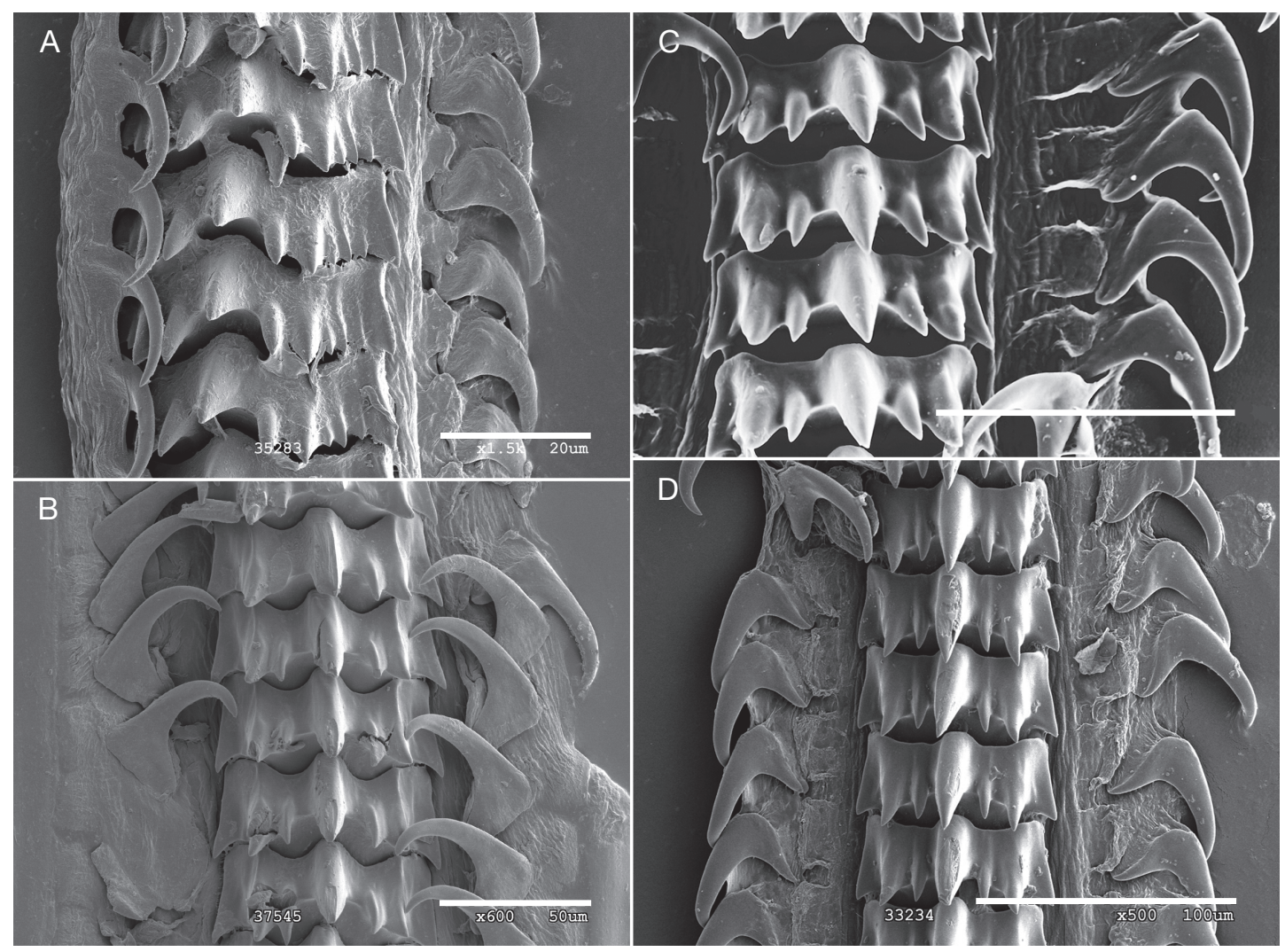

FIG. 5. - A, radula of Murexsul merlei Houart \& Héros, 2008; B, radula of Scabrotrophon inspiratum Houart, 2003; C, radula of Scabrotrophon maltzani (Kobelt \& Küster, 1878), Alaska, Tutka Bay, intertidal, coll. RH; D, radula of Scabrotrophon undocostata

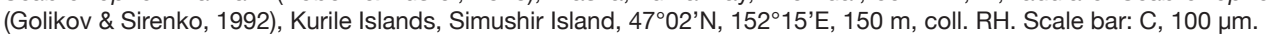

its geographical distribution further north but also provide information about the bathymetrical range of living specimens.

\section{REMARKS}

The largest specimen examined was dead collected and is $46.1 \mathrm{~mm}$ high. The operculum and the radula were also examined.

The operculum is light brown, strongly ovate with an extreme apical nucleus. The radula (Fig. 5B) is trophonine with a short, broad central cusp and a short lateral denticle with a weakly longer and broader lateral cusp on each side. It is quite similar to the radula of S. maltzani (Fig. 5C) and S. undocostata (Golikov \& Sirenko, 1992) from the Kurile Islands (Fig. 5D).

\section{Acknowledgements}

The senior author is much indebted to Philippe Bouchet (MNHN) for allowing him to study the Muricidae collected during the expeditions conducted by MNHN and IRD in the tropical Indo-Pacific. We are also very grateful to Anders Warén (Natural History Museum, Stockholm) for radula preparation and SEM work on the radulae and shell morphology and to the reviewers Bruce Marshall (National Museum of New Zeland, Te Papa Tongarewa) and Marco Oliverio (La Sapienza University, Roma).

Thanks are also due to Margaret N. Dykens, San Diego Natural History Museum, California, for the loan of the holotype and paratype of Pygmaepterys bellini. 


\section{REFERENCES}

Barco A., Claremont M., Reid D. G. Houart R., Bouchet P., Williams S. T., Cruaud C., Couloux A. \& Oliverio M. 2010. - A molecular phylogenetic framework for the Muricidae, a diverse family of carnivorous gastropods. Molecular Phylogenetics and Evolution 56: 1025-1039.

Bouchet P., Héros V., Lozouet P. \& Maestrati P. 2008. - A quarter-century of deep-sea malacological exploration in the south and west Pacific: where do we stand? How far to go?, in Héros V., CowIE R. H. \& BOUCHET P. (eds), Tropical deep-sea benthos 25. Mémoires du Muséum national d'Histoire naturelle 196: 9-40.

HOUART R. 1983. - Three new tropical muricacean species (Gastropoda: Muricidae). Venus 42 (1): 26-33.

HouART R. 1985. - Report on Muricidae (Gastropoda) recently dredged in the southern-western Indian Ocean vol. I. Description of eight new species. Venus 44 (3): 159-171.

HoUART R. 1986. - Mollusca Gastropoda: noteworthy Muricidae from the Pacific Ocean, with description of seven new species. Mémoires du Muséum national d'Histoire naturelle, sér. a, zoologie 133: 427-455.

HOUART R. 1988. - Description of seven new species of Muricidae (Neogastropoda) from the south-western Pacific Ocean. Venus 47 (3): 185-196.

HOUART R. 1990. - New taxa and new records of IndoPacific species of Murex and Haustellum (Gastropoda, Muricidae, Muricinae). Bulletin du Muséum national d'Histoire naturelle Paris, $4^{\circ}$ sér., 12, sect. A, 2: 329-347.

HOUART R. 2003. - Description of Scabrotrophon inspiratum new species (Gastropoda: Muricidae) from Vanuatu. The Nautilus 117 (3): 87-90.

HOUART R. 2004. - A review of Gemixystus Iredale, 1929 (Gastropoda: Muricidae) from Australia and New Zealand. Novapex (HS 2): 1-27.
Houart R. 2008. - Muricidae, in Poppe G. (ed.), Philippine Marine Mollusks. Conchbooks, Hackenheim: 132-220.

HOUART R. 2010. - Litozamia rudolphi (Brazier, 1894). Accessed through: World Register of Marine Species at http://www.marinespecies.org/aphia. php?p=taxdetails\&id=399198 on 2010-12-29.

HouART R. \& Héros V. 2008. - Muricidae (Mollusca: Gastropoda) from Fiji and Tonga, in Héros V., CowIE R. H. \& Bouchet P. (eds), Tropical deep-sea benthos 25. Mémoires du Muséum national d'Histoire naturelle 196: 437-480.

IREDALE T. 1929. - Mollusca from the continental shelf of eastern Australia. Records of the Australian Museum 17: 157-189.

Landau B., Houart R. \& Da Silva C. M. 2007. — The Early Pliocene Gastropoda (Mollusca) of Estepona, southern Spain. Part 7: Muricidae. Palaeontos 11: 1-87.

MerLe D. 1999. — La radiation des Muricidae (Gastropoda: Neogastropoda) au Paléogène: approche phylogénétique et évolutive. $\mathrm{PhD}$ thesis, Muséum national d'Histoire naturelle, Paris: i-vi, 499 p.

Merle D. 2001. - The spiral cords and the internal denticles of the outer lip in the Muricidae: terminology and methodological comments. Novapex 2 (3): 69-91.

Merle D., Garrigues B. \& Pointier J.-P. 2011. - Fossil and Recent Muricidae of the World. Part Muricinae. Conchbooks, Hackenheim, 648 p.

Ponder W. F. \& VOKes E. H. 1988. - Revision of the Indo-West Pacific fossil and Recent species of Murex s.s. and Haustellum (Mollusca: Gastropoda: Muricidae). Records of the Australian Museum, suppl. 8: $1-160$.

THIELE J. 1925. — Gastropoda der Deutschen TiefseeExpedition. II Teil. Wissenschaftenliche Ergebnisse der Deutschen Tiefsee-Expedition aus dem Dampfer Valdivia 1898, 1899, 17 (2): 38-382. 